Research

\title{
Stabilizing mutation of CTNNBI/beta-catenin and protein accumulation analyzed in a large series of parathyroid tumors of Swedish patients
}

\author{
Peyman Björklund, Daniel Lindberg, Göran Åkerström and Gunnar Westin*
}

Address: Department of Surgical Sciences, Endocrine Unit, Uppsala University, Uppsala University Hospital, SE-751 85 Uppsala, Sweden

Email: Peyman Björklund - peyman.bjorklund@surgsci.uu.se; Daniel Lindberg - daniel.lindberg@surgsci.uu.se;

Göran Åkerström - goran.akerstrom@surgsci.uu.se; Gunnar Westin* - gunnar.westin@surgsci.uu.se

* Corresponding author

Published: 9 June 2008

Molecular Cancer 2008, 7:53 doi:10.1/86/1476-4598-7-53
Received: 26 February 2008

Accepted: 9 June 2008

This article is available from: http://www.molecular-cancer.com/content/7/1/53

(c) 2008 Björklund et al; licensee BioMed Central Ltd.

This is an Open Access article distributed under the terms of the Creative Commons Attribution License (http://creativecommons.org/licenses/by/2.0), which permits unrestricted use, distribution, and reproduction in any medium, provided the original work is properly cited.

\begin{abstract}
Background: Aberrant accumulation of $\beta$-catenin plays an important role in a variety of human neoplasms. We recently reported accumulation of $\beta$-catenin in parathyroid adenomas from patients with primary hyperparathyroidism (pHPT). In CTNNBI exon 3, we detected a stabilizing mutation (S37A) in 3 out of 20 analyzed adenomas. The aim of the present study was to determine the frequency and zygosity of mutations in CTNNBI exon 3 , and $\beta$-catenin accumulation in a large series of parathyroid adenomas of Swedish patients.
\end{abstract}

Results: The mutation S37A (TCT > GCT) was detected by direct DNA sequencing of PCR fragments in 6 out of 104 sporadic parathyroid adenomas (5.8\%). Taking our previous study into account, a total of 9 out of $124(7.3 \%)$ adenomas displayed the same mutation. The mutations were homozygous by DNA sequencing, restriction enzyme cleavage, and gene copy number determination using the GeneChip $500 \mathrm{~K}$ Mapping Array Set. All tumors analyzed by immunohistochemistry, including those with mutation, displayed aberrant $\beta$-catenin accumulation. Western blotting revealed a slightly higher expression level of $\beta$-catenin and nonphosphorylated active $\beta$-catenin in tumors with mutation compared to those without. Presence of the mutation was not related to distinct clinical characteristics.

Conclusion: Aberrant accumulation of $\beta$-catenin is very common in parathyroid tumors, and is caused by stabilizing homozygous mutation in $7.3 \%$ of Swedish pHPT patients.

\section{Background}

Parathyroid disease with hypersecretion of parathyroid hormone and generally also hypercalcemia occurs in primary hyperparathyroidism (pHPT), due to growth regulatory disturbance in one or several parathyroid glands. Activation of CCND1 oncogene expression or inactivation of the MEN1 tumor suppressor gene contributes to dereg- ulated growth control in a fraction of sporadic parathyroid adenomas [1-4].

Activation of the Wnt/ $\beta$-catenin signaling pathway by aberrant accumulation of stabilized $\beta$-catenin is involved in the development of many neoplasms. $\beta$-catenin accumulation is typically caused by mutations in components of the signaling pathway, such as APC, Axin, $\beta$-Trcp, and 
WTX, or results from secondary events. In addition, protein stabilizing mutations in the glycogen synthase kinase $3 \beta$ phosphorylation sites of $\beta$-catenin (Ser-33, Ser-37, Thr41 , Ser-45) occur with varying frequency in several neoplasms [5-9].

We recently reported activation of the Wnt $/ \beta$-catenin signaling pathway by aberrant accumulation of $\beta$-catenin in parathyroid adenomas from patients with PHPT [10]. The accumulation of $\beta$-catenin was caused by expression of an aberrantly spliced internally truncated Wnt receptor LRP5 or by a stabilizing mutation (S37A) in CTNNB1 exon 3 $[10,11]$. Stabilizing mutations of CTNNB1 have not been detected in parathyroid adenomas of patients from Japan and the United States [12,13]. Here we have determined the frequency and zygosity of mutations in exon 3 of CTNNB1, and $\beta$-catenin expression status in a large series of parathyroid adenomas of Swedish patients.

\section{Methods}

\section{Tissue Specimens}

Sporadic parathyroid adenomas $(\mathrm{n}=104)$ were acquired from 104 Swedish patients with pHPT diagnosed and operated on in the clinical routine at the Uppsala University Hospital. Normal parathyroid tissue was obtained as normal gland biopsies in patients subjected to parathyroidectomy. Tissues were intraoperatively snap frozen. Informed consent and approval of institutional ethical committee were obtained.

\section{DNA Sequencing}

DNA from parathyroid tumors was prepared by standard procedures including proteinase $\mathrm{K}$ treatment and phenol extraction. Blood DNA was prepared using the Wizard Genomic DNA Purification Kit (Promega Corp., Madison, WI). DNA was PCR amplified with primers for exon 3 of CTNNB1. PCR forward primer: 5'-TGA TGG AGT TGG ACA TGG CC; reverse: 5'-CTC ATA CAG GAC TTG GGA GG. The complementary strand was also sequenced for fragments with mutation. The PCR fragments were sequenced directly on the $3130 x \mathrm{l}$ Genetic Analyzer using the ABI Prism Dye Terminator Cycle Sequencing Ready Reaction kit (Applied Biosystems, Foster City, CA).

\section{Restriction Enzyme Digestion}

CTNNB1 exon 3 PCR fragments were purified using the GFX PCR DNA and Gel Band Purification Kit (GE Healthcare Europe GmbH, Uppsala, Sweden) and cleaved with Xma I or Nla III according to instructions by the manufacturer (New England Biolabs, Inc., Beverly, MA). Products were analyzed by agarose gel electrophoresis.

\section{CTNNBI Gene Copy Number}

Tumor (S37A) and blood DNA from 4 patients were extracted as described above. DNA was marked with fluorescence dye and hybridized to the Affymetrix GeneChip Mapping 500 K Set Arrays 250K_Nsp_SNP and 250K_Sty_SNP according to the manufacturer's instructions, and analysed by GeneChip Genotyping Analysis Software (GTYPE) using Chromosome Copy Number Analysis Tool (CNAT) (Affymetrix, Inc. Santa Clara, California, USA). Informative SNPs used in the gene copy number determination are shown in Table 1. The experiment was performed at the Bioinformatics and Expression Analysis core facility at NOVUM, Karolinska Institute, Huddinge, Sweden.

\section{Immunohistochemistry and Western Blotting}

Frozen tissue sections were stained as described [10] using an anti- $\beta$-catenin goat polyclonal antibody with an epitope mapping at the C-terminus (Santa Cruz Biotechnology, INC., Santa Cruz, CA; catalog no. sc-1496). Protein extracts for Western blotting were prepared [10] in Cytobuster Protein Extract Reagent (Novagen Inc., Madison, Wisconsin, USA) supplemented with Complete protease inhibitor cocktail (Roche Diagnostics $\mathrm{GmbH}$, Penzberg, Germany). The anti-active (nonphosphorylated) $\beta$-catenin [14] mouse monoclonal antibody (Upstate, Lake Placid, USA, \# 05-665), the anti- $\beta$-catenin goat polyclonal antibody (above), and anti-actin goat polyclonal antibody (Santa Cruz Biotechnology INC.) were used. After incubation with the appropriate secondary

Table I: SNP genotyping

\begin{tabular}{|c|c|c|c|c|c|}
\hline SNP position & refSNP ID & Patient I & Patient 2 & Patient 3 & Patient 4 \\
\hline 41205658 & rs7630377 & $\mathrm{ECN}$ & $\mathrm{ECN}$ & $\mathrm{ECN}$ & $\mathrm{ECN}$ \\
\hline 41209520 & rs9859392 & $\mathrm{ECN}$ & $\mathrm{ECN}$ & $\mathrm{ECN}$ & $\mathrm{ECN}$ \\
\hline 41218746 & rs3915129 & $\mathrm{ECN}$ & $\mathrm{NI}$ & $\mathrm{ECN}$ & $\mathrm{ECN}$ \\
\hline 41237448 & rs 13072632 & $\mathrm{ECN}$ & $\mathrm{ECN}$ & $\mathrm{ECN}$ & $\mathrm{ECN}$ \\
\hline 41243358 & rsII564447 & $\mathrm{ECN}$ & $\mathrm{ECN}$ & $\mathrm{NI}$ & $\mathrm{ECN}$ \\
\hline 41262697 & rs9824212 & $\mathrm{ECN}$ & $\mathrm{ECN}$ & $\mathrm{ECN}$ & ECN \\
\hline $4|2687| 1$ & rs 1880480 & $\mathrm{ECN}$ & ECN & $\mathrm{ECN}$ & $\mathrm{ECN}$ \\
\hline
\end{tabular}

Constitutional DNA and parathyroid adenoma DNA with CTNNBI mutation S37A from 4 pHPT patients were genotyped with the GeneChip 500 K Mapping Array Set. The CTNNBI gene is located between positions 4/216016 and 4I 256928 http://genome.ucsc.edu. ECN, equal copy number. $\mathrm{NI}$, non-informative. 
antibodies, bands were visualized using the enhanced chemiluminescence system (GE Healthcare Europe $\mathrm{GmbH}$, Uppsala, Sweden). Membranes were scanned by the ChemiDoc XRS and the band intensities were determined using Quantity One Software (Bio-Rad Laboratories, Inc., Hercules, California, USA).

\section{Statistical Analyses}

Unpaired $t$ test, $z$ test, and $\chi^{2}$ test were used. The data were calculated with Statistica 6 (StatSoft, Tulsa, OK, USA). Values are presented as arithmetrical mean \pm SEM.

\section{Results}

Homozygous CTNNBI Stabilizing Mutation S37A

DNA sequencing analysis detected the CTNNB1 stabilizing mutation S37A (TCT > GCT) in 6 out of the 104 $(5.8 \%)$ analyzed parathyroid adenomas (Figure 1). Constitutional DNA (blood) from 4 out of the 6 patients were available, and encoded the wild-type CTNNB1 sequence. The mutations were apparently homozygous by DNA sequencing (Figure 1), as we reported previously for 3 out of 20 adenomas [10]. Taking our previous study into account [10], a total of 9 out of 124 (7.3\%) randomly selected parathyroid adenomas displayed the CTNNB1 stabilizing mutation S37A.

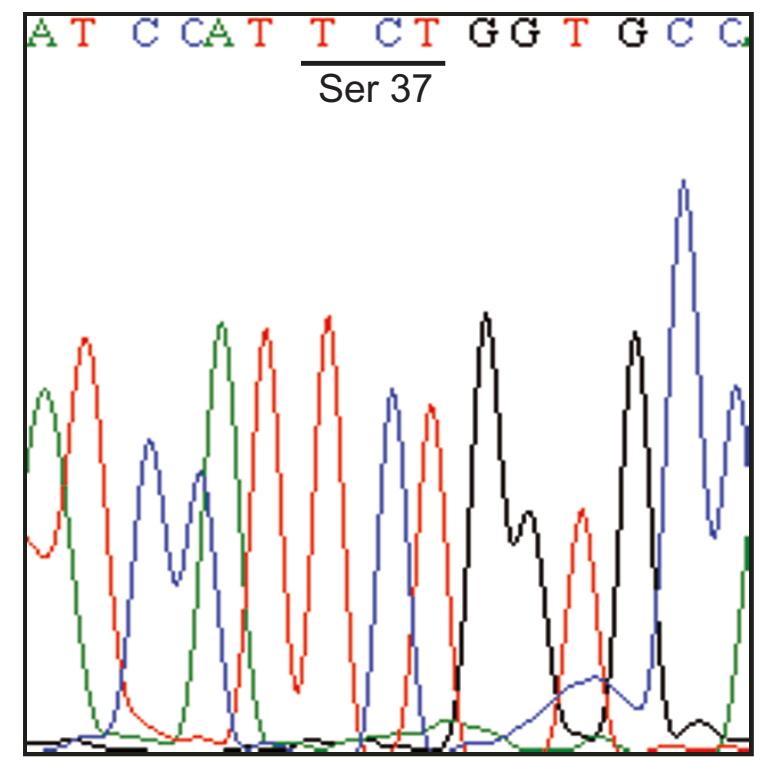

Constitutional DNA
Homozygosity for the mutation was further substantiated by analytical restriction enzyme digestions. As expected, all 9 fragments harbouring S37A were completely cleaved by Nla III and not by Xma I (Figure 2A). Vice versa was observed for fragments with the wild-type codon S37. PCR amplified fragments were used for the DNA sequencing and restriction analyses, and PCR reactions could in theory favour the mutant allele(s). Unbiased PCR reactions were however confirmed by performing PCR amplification in a 1:1 mixture of constitutional DNA and S37A mutant tumor DNA, and by subsequent analytical restriction enzyme digestion (Figure 2B).

In order to resolve the issue of zygosity for the S37A mutation, 4 tumor DNAs with the corresponding constitutional DNAs were genotyped with the GeneChip $500 \mathrm{~K}$ Mapping Array Set (Affymetrix). Gene copy number analysis was done by comparison of informative single-nucleotide polymorphisms (SNPs). Five informative SNPs in CTNNB1 and 2 SNPs downstream of the gene showed equal copy number for the 4 paired DNA samples (Table $1)$. Thus, taking also the DNA sequencing results into account the S37A mutation was homozygous in these 4 tumours, rather than hemizygous with one mutant and one deleted CTNNB1 allele.

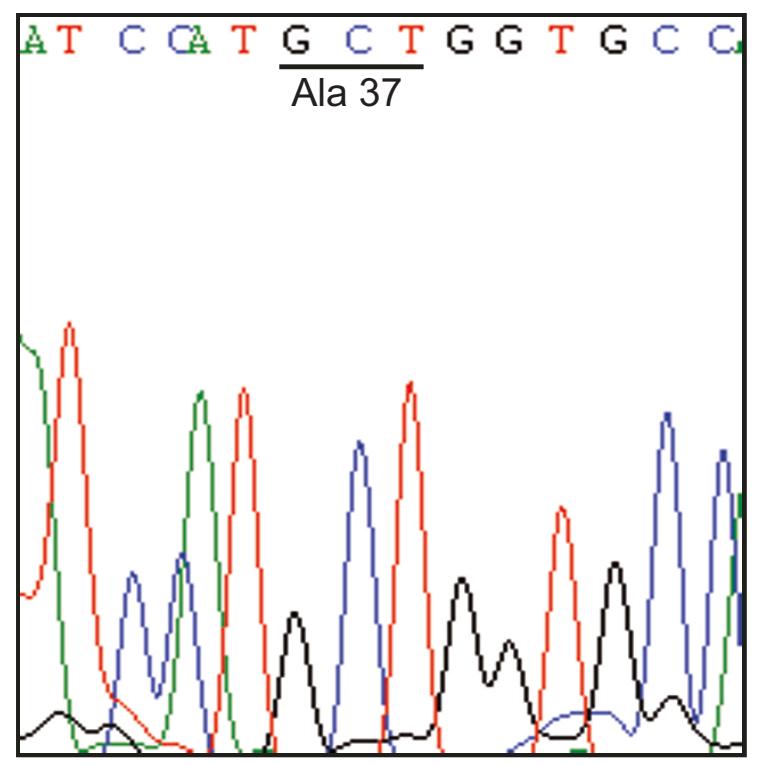

\section{Tumor DNA}

\section{Figure I}

Representative results of direct DNA sequencing of CTNNBI exon 3. Constitutional DNA from blood (left panel) and parathyroid adenoma (right panel) of the same PHPT patient. 
A

\begin{tabular}{|c|c|c|}
\hline & $\underline{\mathrm{S} 37}$ & \\
\hline & GGAATC CAT TCT GGT & $\mathrm{Wt}$ \\
\hline & GGAATC CAT GCT GGT & S37A mutant \\
\hline Restriction endonuclease & GA ANN NNT TC & Xmn I cuts only wt \\
\hline sites & CAT $\mathbf{G}$ & Nla III cuts only mutant \\
\hline
\end{tabular}

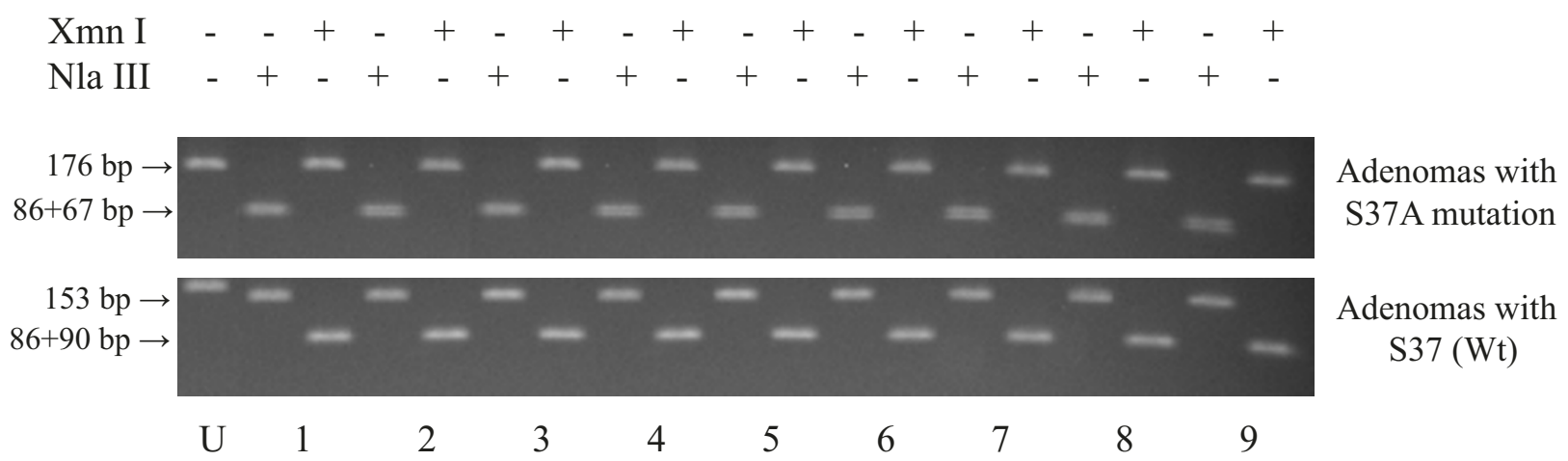

B

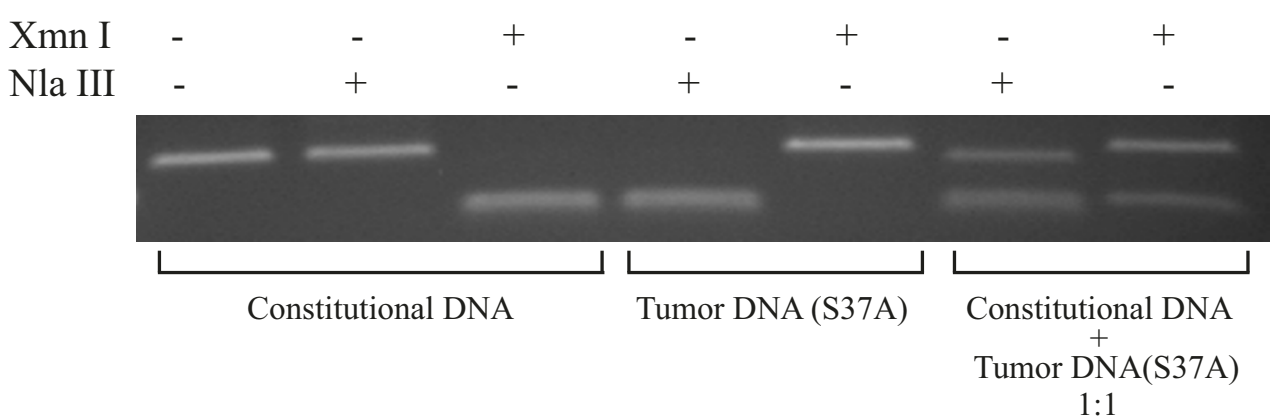

Figure 2

Analytical restriction enzyme cleavage analysis. (A), CTNNBI exon 3 PCR fragments (I76 bp) were digested with Xmn I or Nla III that cuts only wild-type or only S37A mutant sequences, respectively. Three out of the nine parathyroid adenomas with S37A mutation were identified in our previous study [10]. Nla III cuts also outside of codon 37, close to the fragment end (23 bp). U; uncleaved CTNNBI exon 3 PCR fragment. (B), CTNNBI exon 3 was PCR amplified from a I:I mixture of constitutional DNA and tumor DNA with the S37A mutation. The fragment was analyzed by restriction enzyme digestions as in (A). 


\section{$\beta$-catenin Protein Expression}

Previously, we reported aberrant accumulation of $\beta$-catenin in all $(n=37)$ analyzed parathyroid adenomas [10]. Of the tumors analyzed here by DNA sequencing, 81 frozen parathyroid adenomas, including 6 with the S37A mutation, were of sufficient good quality for immunohistochemical analysis with a $\beta$-catenin goat polyclonal peptide antiserum [10]. The three pHPT tumors with S37A mutation described previously [10] were also included. In addition to membraneous staining, all 84 tumors displayed distinct cytoplasmic/nuclear immunoreactivity (Figure 3). Western blotting analysis was performed to compare the expression level of $\beta$-catenin as well as of nonphosphorylated active $\beta$-catenin (ratio of $\beta$-catenin to actin) in tumors with $(n=8)$ and without $(n=6)$ the stabilizing mutation S37A (Figure 4). The six tumors without $\beta$-catenin stabilizing mutation all expressed the internally truncated LRP5 receptor [11], and as expected [10,11] all fourteen tumors showed accumulation of nonphosphorylated active $\beta$-catenin in comparison to normal parathyroid tissue (not shown). A small but significantly higher expression level was observed of both $\beta$-catenin and nonphosphorylated active $\beta$-catenin in tumors with stabilizing mutation S37A in comparison to those with wild type $\beta$-catenin. The ratio of nonphosphorylated active $\beta$-catenin to $\beta$-catenin was also slightly higher in tumors with $\beta$-catenin stabilizing mutation (Figure 4 ). No particular clinical characteristics, including age, sex, serum calcium level, serum PTH level or gland weight related to presence of the S37A mutation.

\section{Discussion}

We have found that a total of 9 out of 124 (7.3\%) randomly selected parathyroid adenomas displayed the CTNNB1 stabilizing homozygous mutation S37A. None of these 9 tumors expressed the internally truncated LRP5 receptor [11] (data not shown), further emphasizing the previous observation that these events are mutually exclusive [11]. The mutated LRP5 receptor, with the central region deleted, is expressed in the majority of pHPT tumors and is required for accumulation of $\beta$-catenin and parathyroid tumor cell growth [11].

The S37A CTNNB1 mutation commonly occurs also in gastrointestinal carcinoid tumors where 26 out of 29 tumors with mutations harboured S37A [15]. The mutant protein shows resistance to ubiquination and proteosomal degradation, with a longer half-life than wild-type $\beta$-catenin. S37A $\beta$-catenin also shows an enhanced affinity for LEF1 and TCF4, its DNA-binding partners in transcriptional regulation [16-18]. Homozygous mutation as detected by direct DNA sequencing of CTNNB1 seems to be uncommon in other neoplasms, but have been described in a rectal carcinoid tumor and in colorectal cancer $[15,19]$. To be conclusive regarding zygosity, direct
DNA sequencing clearly requires low or no contamination of normal cell populations in the tumor sample. In colorectal cancer cells with inactivating APC hemizygous mutation or activating CTNNB1 heterozygous mutation, the total $\beta$-catenin signaling activity seemed dependent also on silencing of SFRP genes by promoter hypermethylation with consistent constitutive WNT signaling [20]. Whether combined activity of two mutant S37A CTNNB1 alleles suffices for benign parathyroid tumor growth or whether constitutive WNT signaling is required in addition, remain to be investigated.

DNA sequence analysis of 24 parathyroid adenomas from Japanese patients revealed no CTNNB1 mutations, and immunohistochemistry showed weak cytoplasmic $\beta$-catenin staining in 2 tumors [12]. In another study from Japan $(n=9)$, cytoplasmic and/or membranous $\beta$-catenin staining was seen in 8 adenomas and nuclear staining in one adenoma. DNA sequencing analysis was not done in these specimens [21]. Furthermore, a recent study did not detect CTNNB1 exon 3 mutations in 97 sporadic parathyroid adenomas from patients who had undergone parathyroidectomy in the United States. Unfortunately, $\beta$ catenin protein expression was not evaluated in this report [13]. Since we observed a CTNNB1 mutation frequency of $7.3 \%$ in adenomas from Swedish patients, this may suggest possible contribution of geographical origin (dietary or environmental differences, or different genetic backgrounds) to mechanisms of parathyroid disease. The CTNNB1 mutation frequency vary considerably also in colorectal cancer (1-60\%) and melanomas (0.02-27\%), apparently not related to geographical origin $[8,17,22$ 30]. The observations may be attributed to the stochastic distribution of probability in analyzed material or to other causalities, like that the tumor sample purity and pathology must be guaranteed.

\section{Conclusion}

By analyzing a large series of tumors from Swedish patients, this study further emphasizes $\beta$-catenin accumulation as the most common aberration in parathyroid tumors of primary origin. CTNNB1-stabilizing mutations were found in $5.8 \%$ of the tumors, or in $7.3 \%$ when taking our previous study [10] into account. The WNT/ $\beta$-catenin signaling pathway, with $\beta$-catenin and the internally truncated LRP5 receptor [11] in particular, present therapeutic targets for hyperparathyroidism.

\section{Competing interests}

The authors declare that they have no competing interests.

\section{Authors' contributions}

PB participated in the design of the study, performed experiments, analyzed data and performed the statistical analysis, DL analyzed the data, GA helped to draft the 

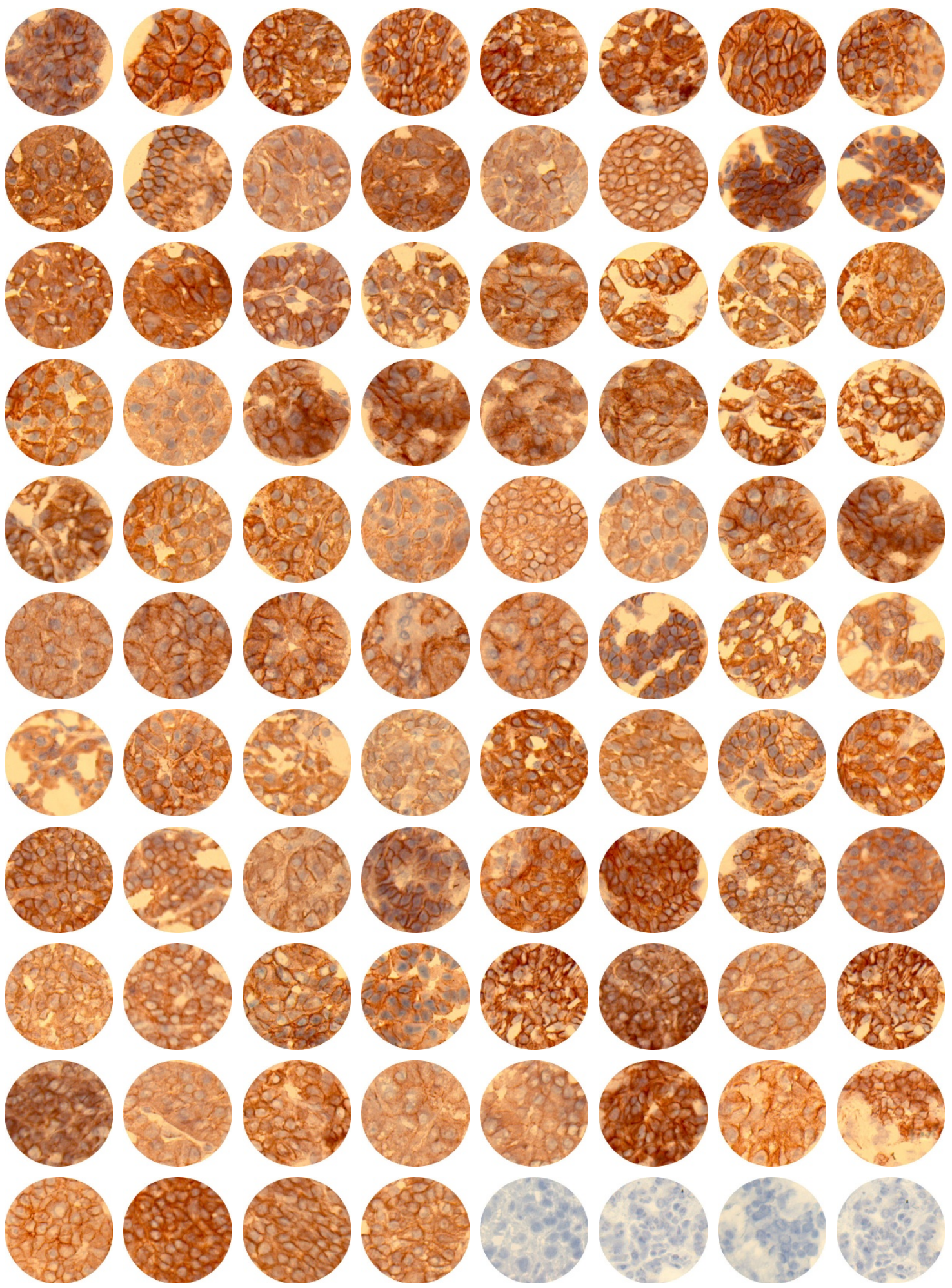

Figure 3

Immunohistochemical analysis of $\beta$-catenin. Immunostaining of 84 parathyroid adenomas with an anti- $\beta$-catenin goat polyclonal antibody. The first 9 tumor specimens, of which 3 were described previously [10], displayed CTNNBI homozygous stabilizing mutation S37A. No staining was seen in the absence of primary antibodies (last 4 specimens). 

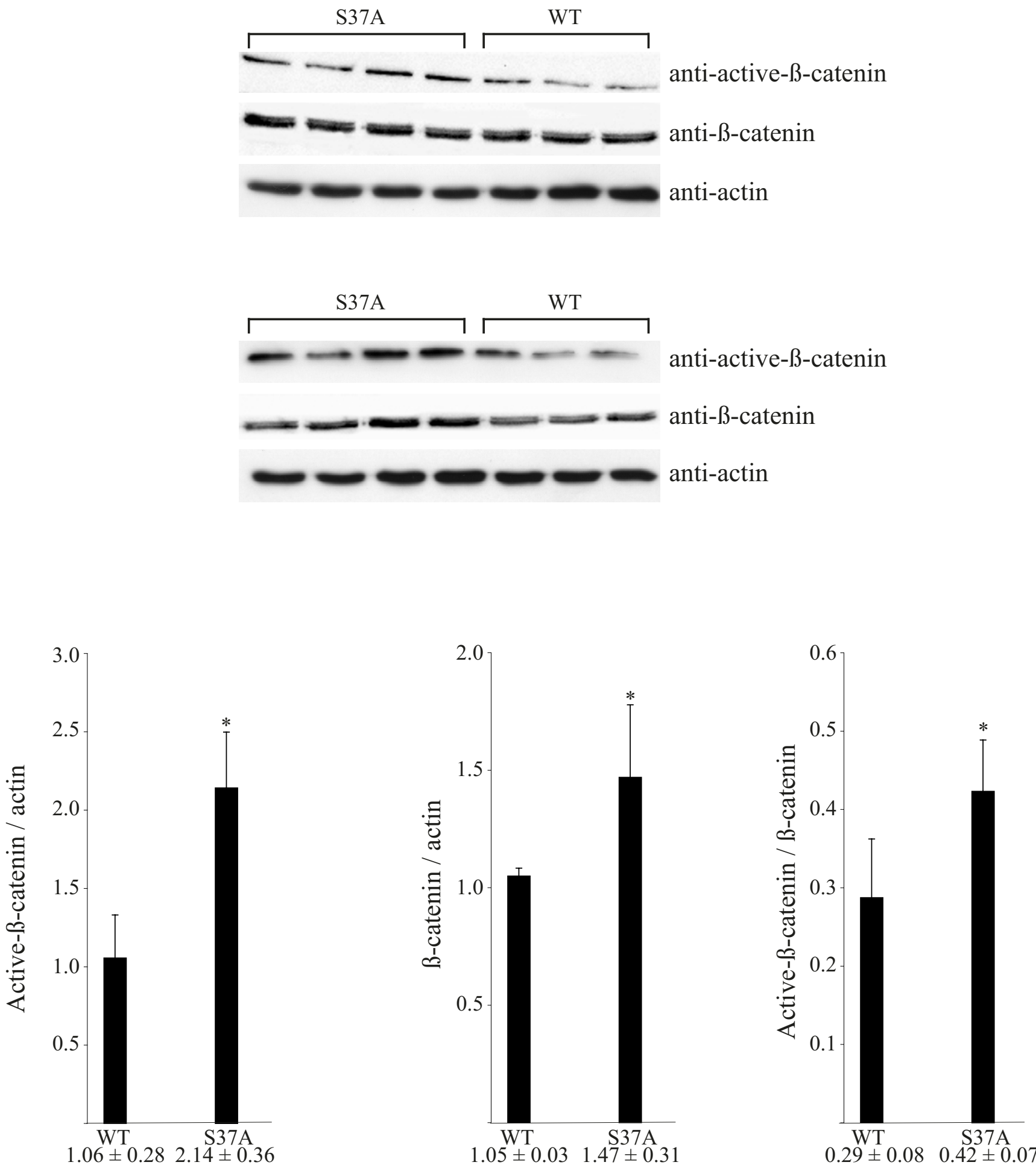

Figure 4

Western blotting analysis of total and non-phosphorylated active $\beta$-catenin. Eight pHPT tumors with CTNNBI mutation S37A and six PHPT tumors without mutation were analyzed. The group of six tumors expressed the internally truncated LRP5 receptor [I I]. All analyzed tumors showed accumulation of active $\beta$-catenin in comparison to normal parathyroid tissue (not shown). An anti-active (nonphosphorylated) $\beta$-catenin monoclonal antibody [14] and a goat polyclonal antibody with an epitope mapping at the C-terminus of $\beta$-catenin were used. Quantisation of the obtained signals are shown below. *, $\mathrm{p}<0.05$. 
manuscript, GW conceived of the study, participated in its design and coordination and drafted the manuscript. All authors read and approved the final manuscript.

\section{Acknowledgements}

This work was supported by the Swedish Research Council and Swedish Cancer Society. We thank the referee of another paper for suggesting the use of Xma I and Nla III. We are grateful to Birgitta Bondeson and Peter Lillhager for skilful technical assistance. We are also grateful to Marika Rönnholm at the Bioinformatics and Expression Analysis core facility at NOVUM, Karolinska Institute, Huddinge, Sweden.

\section{References}

I. Marx S: Hyperparathyroid and hypoparathyroid disorders. $\mathrm{N}$ Engl J Med 2000, 343: I863-1875.

2. Arnold A, Shattuck TM, Mallya SM, Krebs LJ, Costa J, Gallagher J, Wild Y, Saucier K: Molecular pathogenesis of primary hyperparathyroidism. J Bone Miner Res 2002, I7(Suppl 2):N30-36.

3. Åkerström G, Hellman P: Primary hyperparathyroidism. Curr Opin Oncol 2004, 16:1-7.

4. Åkerström G, Hellman P, Hessman O, Segersten U, Westin G: Parathyroid glands in calcium regulation and human disease. Ann N Y Acad Sci 2005, 1040:53-58.

5. Polakis P: The oncogenic activation of $\beta$-catenin. Curr Opin Genet Dev 1999, 9:15-21.

6. Lustig $B$, Behrens J: The Wnt signaling pathway and its role in tumor development. J Cancer Res Clin Oncol 2003, I 29:199-221.

7. Giles RH, van Es JH, Clevers H: Caught up in a Wnt storm: Wnt signaling in cancer. Biochim Biophys Acta 2003, 1653:I-24.

8. Polakis P: The many ways of Wnt in cancer. Curr Opin Genet Dev 2007, | 7:45-5I.

9. Major MB, Camp ND, Berndt JD, Yi X, Goldenberg SJ, Hubbert C, Biechele TL, Gingras AC, Zheng N, Maccoss MJ, Angers S, Moon RT: Wilms tumor suppressor WTX negatively regulates WNTI $\beta$-catenin signaling. Science 2007, 31 6:1043-1046.

10. Björklund P, Ảkerström G, Westin G: Accumulation of nonphosphorylated $\beta$-catenin and c-myc in primary and uremic secondary hyperparathyroid tumors. J Clin Endocrinol Metab 2007, 92:338-344.

11. Björklund P, Åkerström G, Westin G: An LRP5 receptor with internal deletion in hyperparathyroid tumors with implications for deregulated WNT/ $\beta$-catenin signaling. PLoS Med 2007, 4(I I):e328.

12. Ikeda S, Ishizaki Y, Shimizu Y, Fujimori M, Ojima Y, Okajima M, Sugino $\mathrm{K}$, Asahara T: Immunohistochemistry of cyclin DI and $\beta$-catenin, and mutational analysis of exon 3 of $\beta$-catenin gene in parathyroid tumors. Int J Oncol 2002, 20:463-466.

13. Costa-Guda J, Arnold A: Absence of stabilizing mutations of $\beta$ catenin encoded by CTNNB I exon 3 in a large series of sporadic parathyroid adenomas. J Clin Endocrinol Metab 2007, 92:1564-I566.

14. van Noort M, Meeldijk J, Zee R van der, Destree O, Clevers H: Wnt signaling controls the phosphorylation status of beta-catenin. J Biol Chem 2002, 277: 1790I-I7905.

15. Fujimori M, Ikeda S, Shimizu Y, Okajima M, Asahara T: Accumulation of $\beta$-catenin protein and mutations in exon 3 of $\beta$-catenin gene in gastrointestinal carcinoid tumor. Cancer Res 200I, 6I:6656-6659.

16. Orford K, Crockett C, Jensen JP, Weissman AM, Byers SW: Serine phosphorylation-regulated ubiquitination and degradation of $\beta$-catenin. J Biol Chem 1997, 272:24735-24738.

17. Rubinfeld B, Robbins P, El-Gamil M, Albert I, Porfiri E, Polakis P: Stabilization of $\beta$-catenin by genetic defects in melanoma cell lines. Science 1997, 275:1790-1792.

18. Williams BO, Barish GD, Klymkowsky MW, Varmus HE: A comparative evaluation of $\beta$-catenin and plakoglobin signaling activity. Oncogene 2000, 19:5720-5728.

19. Ilyas M, Tomlinson IPM, Rowan A, Pignatelli M, Bodmer WF: $\beta$-Catenin mutations in cell lines established from human colorectal cancers. Proc Natl Acad Sci USA 1997, 94:10330-10334.

20. Suzuki H, Watkins DN, Jair KW, Schuebel KE, Markowitz SD, Chen WD, Pretlow TP, Yang B, Akiyama Y, Van Engeland M, Toyota M, Tokino T, Hinoda Y, Imai K, Herman JG, Baylin SB: Epigenetic inac- tivation of SFRP genes allows constitutive WNT signaling in colorectal cancer. Nat Genet 2004, 36:417-422.

21. Semba S, Kusumi R, Moriya T, Sasano H: Nuclear accumulation of $\beta$-catenin in human endocrine tumors: Association with $\mathrm{Ki}$ 67 (MIB-I) proliferative activity. Endocr Pathol 2000, I I:243-250.

22. Morin PJ, Sparks AB, Korinek V, Barker N, Clevers H, Vogelstein B, Kinzler KW: Activation of beta-catenin-Tcf signaling in colon cancer by mutations in beta-catenin or APC. Science 1997, 275: 1787-1790.

23. Sparks AB, Morin PJ, Vogelstein B, Kinzler KW: Mutational analysis of the APC/beta-catenin/Tcf pathway in colorectal cancer. Cancer Res 1998, 58: | |30-1 |34.

24. Omholt K, Platz A, Ringborg U, Hansson J: Cytoplasmic and nuclear accumulation of beta-catenin is rarely caused by CTNNBI exon 3 mutations in cutaneous malignant melanoma. Int J Cancer 200I, 92:839-842.

25. Reifenberger J, Knobbe CB, Wolter M, Blaschke B, Schulte KW, Pietsch T, Ruzicka T, Reifenberger G: Molecular genetic analysis of malignant melanomas for aberrations of the WNT signaling pathway genes CTNNBI, APC, ICAT and BTRC. Int J Cancer 2002, 100:549-556.

26. Pollock PM, Hayward N: Mutations in exon 3 of the beta-catenin gene are rare in melanoma cell lines. Melanoma Res 2002, 1 2: $183-186$

27. Demunter A, Libbrecht L, Degreef H, De Wolf-Peeters C, Oord IJ van den: Loss of membranous expression of beta-catenin is associated with tumor progression in cutaneous melanoma and rarely caused by exon 3 mutations. Mod Pathol 2002, I5:454-46I.

28. Johnson V, Volikos E, Halford SE, Eftekhar Sadat ET, Popat S, Talbot I, Truninger K, Martin J, Jass J, Houlston R, Atkin W, Tomlinson IPM, Silver ARJ: Exon 3 beta-catenin mutations are specifically associated with colorectal carcinomas in hereditary nonpolyposis colorectal cancer syndrome. Gut 2005, 54:264-267.

29. Luchtenborg M, Weijenberg MP, Wark PA, Saritas AM, Roemen GM, van Muijen GN, de Bruine AP, Brandt PA van den, de Goeij AF: Mutations in APC, CTNNBI and K-ras genes and expression of hMLHI in sporadic colorectal carcinomas from the Netherlands Cohort Study. BMC Cancer 2005, 5:160.

30. Thorstensen L, Lind GE, Lovig T, Diep CB, Meling GI, Rognum TO, Lothe RA: Genetic and epigenetic changes of components affecting the WNT pathway in colorectal carcinomas stratified by microsatellite instability. Neoplasia 2005, 7:99-108.
Publish with BioMed Central and every scientist can read your work free of charge

"BioMed Central will be the most significant development for disseminating the results of biomedical research in our lifetime."

Sir Paul Nurse, Cancer Research UK

Your research papers will be:

- available free of charge to the entire biomedical community

- peer reviewed and published immediately upon acceptance

- cited in PubMed and archived on PubMed Central

- yours - you keep the copyright

Submit your manuscript here:

http://www.biomedcentral.com/info/publishing_adv.asp
BioMedcentral 